\title{
Mesoporous $\mathrm{PtSnO}_{2} / \mathrm{C}$ Catalyst with Enhanced Catalytic Activity for Ethanol Electro-oxidation
}

\author{
S. Y. Chen, ${ }^{a}$ L. Shi, ${ }^{a}{ }^{*}$ and L. Wang ${ }^{c}$ \\ a School of Chemistry and Chemical Engineering, Shihezi University, \\ Shihezi, Xinjiang, 832 000, P.R. China \\ ${ }^{b}$ Key Laboratory for Green Processing of Chemical Engineering of Xinjiang Bingtuan, \\ Shihezi, Xinjiang, 832 000, P.R. China \\ Shandong University of Traditional Chinese Medicine, Shandong, 250 355, P.R. China
}

\begin{abstract}
In this paper, we report the synthesis, characterization, and electrochemical evaluation of a mesoporous $\mathrm{PtSnO} / \mathrm{C}$ catalyst, called $\mathrm{PtSnO}_{2}(\mathrm{M}) / \mathrm{C}$, with a nominal Pt: Sn ratio of $3: 1$. Brunauer-Emmett-Teller and transmission electron microscopy characterizations showed the obvious mesoporous structure of $\mathrm{SnO}_{2}$ in $\mathrm{PtSnO}_{2}(\mathrm{M}) / \mathrm{C}$ catalyst. X-ray photoelectron spectroscopy analysis exhibited the interaction between $\mathrm{Pt}$ and mesoporous $\mathrm{SnO}_{2}$. Compared with $\mathrm{Pt} / \mathrm{C}$ and commercial $\mathrm{PtSnO} \mathrm{O}_{2} / \mathrm{C}$ catalysts, $\mathrm{PtSnO}_{2}(\mathrm{M}) / \mathrm{C}$ catalyst has a lower active site, but higher catalytic activity for ethanol electro-oxidation reaction (EOR). The enhanced activity could be attributed to Pt nanoparticles deposited on mesoporous $\mathrm{SnO}_{2}$ that could decrease the amount of poisonous intermediates produced during EOR by the interaction between Pt and mesoporous $\mathrm{SnO}_{2}$.
\end{abstract}

Keywords

Ethanol electro-oxidation reaction, Pt-Sn catalyst, mesoporous $\mathrm{SnO}_{2}$, enhanced catalytic activity

\section{Introduction}

The direct ethanol fuel cell (DEFC) has been extensively investigated because ethanol is regarded as one of the potential fuels for $\mathrm{H}_{2}$ and methanol in polymer electrolyte membrane fuel cell applications. However, the ethanol oxidation reaction (EOR) that occurs in the fuel cell anode is slow and incomplete, thus reducing the anode catalytic performance of DEFC. Many investigations have been conducted to improve the anode performance of DEFC. The Pt-Sn catalyst was reported to be the most effective catalyst for EOR compared with other Pt-based binary catalysts ${ }^{1,2}$ because of its enhanced ability to break the $\mathrm{C}-\mathrm{C}$ bond and improved resistance to poison from CO-like intermediates produced during ethanol oxidation reaction..$^{3-5}$ However, the activity of Pt-Sn catalyst still cannot satisfy the criteria for commercial DEFC anode catalyst. Therefore, catalytic performance should be improved further by redesigning Pt-Sn catalyst.

The role of $\mathrm{SnO}_{2}$ on the enhanced EOR activity of Pt-Sn catalysts has been extensively investigated. ${ }^{6,7}$ Recently, some investigators have reported that $\mathrm{SnO}_{2}$ species can produce hydroxy radical species at lower potential than Pt. Thus, CO-like intermediate residues react with hydroxy radical species in the vicinity of Pt particles to free Pt active sites based on the bifunctional mechanism. ${ }^{8,9} \mathrm{SnO}_{2}$ also improves the cycling stability of Pt-Sn catalysts because of its corrosion-resistant property. However, some investiga-

${ }^{*}$ Corresponding author: Lei Shi

e-mail:16105807@qq.com tions determined that $\mathrm{SnO}_{2}$ nanoparticles are fully coated with the Pt layer. These nanoparticles cannot produce hydroxy radical species to increase the $\mathrm{CO}$ tolerance of the catalyst based on the bifunctional mechanism. ${ }^{10} \mathrm{Pt}$ particles are poisoned by CO-like species if no direct contact occurs between Pt particles and $\mathrm{SnO}_{2} \cdot{ }^{11}$ Several studies have recently focused on $\mathrm{PtSnO}_{2}$ systems that exhibit high catalytic activity for ethanol oxidation. Zhang et al. ${ }^{12}$ determined that Pt supported on $\mathrm{SnO}_{2}$ flower-shaped catalyst demonstrates high electrocatalytic activity and long-term cycle stability because of the multi-dimensional active sites and radial channels of liquid diffusion. Zhang et al. ${ }^{11}$ showed that Pt/(CNT@SnO ${ }_{2}$ catalysts exhibit significantly higher catalytic activity and CO tolerance for ethanol electro-oxidation than Pt/CNT. Pt-Sn catalysts can improve EOR activity by alloying with a third metal (Ir or Rh). ${ }^{5,13}$ Ternary PtRhSnO${ }_{2}$ electrocatalyst for ethanol oxidation can be significantly improved because $\mathrm{SnO}_{2}$ supplies hydroxy radical species, whereas $\mathrm{Rh}$ can be induced to break the $\mathrm{C}-\mathrm{C}$ bond at room temperature. ${ }^{13} \mathrm{Li}$ et al. ${ }^{5}$ determined that $\mathrm{PtIrSnO} / 2 / \mathrm{C}$ catalyst with high Ir content exhibits outstanding catalytic properties for EOR and good selectivity toward complete oxidation of ethanol to $\mathrm{CO}_{2}$. However, $\mathrm{Rh}$ and $\mathrm{Ir}$ are rare and costly precious metals. It has been suggested that some non-noble metal oxides possess good capacity for preventing $\mathrm{CO}$ poisoning. ${ }^{14,15}$ Therefore, in this work, we will try to enhance the performance of Pt catalyst for ethanol oxidation through forming mesoporous $\mathrm{PtSnO}_{2}$ nanoparticles.

Although considerable effort has been exerted to prepare mesoporous $\mathrm{SnO}_{2}$ nanomaterials because of their excel- 
lent properties for application in Li-ion batteries and gas sensors, ${ }^{16,17}$ the catalytic behaviour of mesoporous $\mathrm{SnO}_{2}$ toward EOR has been rarely studied. In the present work, we prepared C-supported electrocatalysts that consist of a mesoporous $\mathrm{SnO}_{2}$ core decorated with Pt nanoislands via modified polyol method. We hypothesized that this special catalyst structure will increase the catalytic activity and $\mathrm{CO}$ tolerance of Pt to ethanol oxidation.

\section{Experiment details}

\subsection{Materials}

$\mathrm{H}_{2} \mathrm{PtCl}_{6} \cdot 6 \mathrm{H}_{2} \mathrm{O}, \mathrm{SnCl}_{2} \cdot 2 \mathrm{H}_{2} \mathrm{O}, \mathrm{Na}_{2} \mathrm{SnO}_{3} \cdot \mathrm{H}_{2} \mathrm{O}$, oleic acid, ethylene glycol (EG), $\mathrm{H}_{2} \mathrm{SO}_{4}$, ethanol, and Nafion were purchased from Sigma-Aldrich, St. Louis, Mo, USA. Vulcan XC72R carbon black $\left(S_{\mathrm{BET}}=250 \mathrm{~m}^{2} \mathrm{~g}^{-1}\right)$ was purchased from Cabot Corporation, Boston, MA, USA. All chemicals were of analytical grade and used as received without further purification.

\subsection{Synthesis of mesoporous $\mathrm{SnO}_{2}$}

Mesoporous $\mathrm{SnO}_{2}$ was synthesized via a water-evaporating process that was previously reported in. ${ }^{18}$ In this process, $0.45 \mathrm{~g} \mathrm{Na}_{2} \mathrm{SnO}_{3} \cdot 3 \mathrm{H}_{2} \mathrm{O}$ was added into $5 \mathrm{ml}$ distilled water in an open container. After $\mathrm{Na}_{2} \mathrm{SnO}_{3} \cdot 3 \mathrm{H}_{2} \mathrm{O}$ had completely dissolved, $25 \mathrm{ml}$ oleic acid was added to the $\mathrm{Na}_{2} \mathrm{SnO}_{3}$ solution. The container was maintained at $150{ }^{\circ} \mathrm{C}$ for $5 \mathrm{~h}$ at ambient pressure, and then allowed to cool to room temperature naturally. The resulting precipitate was filtered, washed, and dried at $60{ }^{\circ} \mathrm{C}$ for $12 \mathrm{~h}$. Finally, the solid was further treated at $300{ }^{\circ} \mathrm{C}$ in air for $2 \mathrm{~h}$ to obtain $\mathrm{SnO}_{2}$ mesoporous nanomaterials.

\subsection{Synthesis of $\mathrm{PtSnO}_{2}(\mathrm{M}) / \mathrm{C}$ catalyst}

The appropriate amount of mesoporous $\mathrm{SnO}_{2}$ was first dissolved in $50 \mathrm{ml} \mathrm{EG}$ and sonicated for $0.5 \mathrm{~h}$. The appropriate amount of $\mathrm{H}_{2} \mathrm{PtCl}_{6} \cdot 6 \mathrm{H}_{2} \mathrm{O}$ was then added. The solution was heated to $130{ }^{\circ} \mathrm{C}$ and maintained at this temperature for $2 \mathrm{~h}$. The solution cooled down to $60^{\circ} \mathrm{C}$. Afterward, the appropriate amount of $\mathrm{XC7} 2 \mathrm{R}$ carbon black was added to the solution, an aqueous solution of $\mathrm{HCl}(1.5 \mathrm{M})$ was added to adjust the $\mathrm{pH}$ of the solution to approximately 1 . The solution was then stirred for another $6 \mathrm{~h}$ and cooled down to room temperature. The obtained mixture was filtered, washed, and dried.

For comparison, $\mathrm{PtSnO}_{2}(\mathrm{~N}) / \mathrm{C}$ catalyst was synthesized in a manner similar to that of $\mathrm{PtSnO}_{2}(\mathrm{M}) / \mathrm{C}$ catalyst, except for the preparation of $\mathrm{SnO}_{2}$ nanoparticles. $\mathrm{SnO}_{2}$ nanoparticles were obtained through the following steps. The appropriate amount of $\mathrm{SnCl}_{2} \cdot 2 \mathrm{H}_{2} \mathrm{O}$ was firstly dissolved in $50 \mathrm{ml}$ EG and $1 \mathrm{ml}$ water to form a solution. The solution was then heated to $180{ }^{\circ} \mathrm{C}$, maintained at this temperature for $2 \mathrm{~h}$, and cooled to room temperature. $\mathrm{Pt} / \mathrm{C}$ was also prepared without adding $\mathrm{SnO}_{2}$. The mass fraction of Pt in the catalyst was $w(\mathrm{Pt})=0.20$.

\subsection{Characterization of catalysts}

Brunauer-Emmett-Teller (BET) surface area analysis was performed from the nitrogen adsorption isotherms at $77 \mathrm{~K}$ using an ASAP 2020 physisorption analyser (Micromeritics Instrument Corporation, Norcross, GA, USA). All samples were degassed at $110{ }^{\circ} \mathrm{C}$ under vacuum for $6 \mathrm{~h}$. Average pore diameter $\left(d_{\mathrm{av}}\right)$ and pore volume were calculated based on the Barrett-Joyner-Halenda (BJH) method. Powder X-ray diffraction (XRD) data were collected on a D8 ADVANCE X-ray diffractometer (Bruker Biosciences Corporation, Billerica, MA, USA) using $\mathrm{Cu} \mathrm{K} \alpha$ irradiation $(\lambda=1.5406 \AA)$ as source at $40 \mathrm{kV}$ and $40 \mathrm{~mA}$. Transmission electron microscopy (TEM) experiments were conducted using Tecnai F30 field emission transmission electron microscope (FEl, Hillsboro, OR, USA). Inductively coupled plasma atomic emission spectroscopy (ICP-AES) was conducted using the TCAP 6000 SERICS ICP emission spectrometer. X-ray photoelectron spectroscopy (XPS) analyses were performed on ESCA 3400 (Kratos Analytical Ltd., Manchester, UK) equipped with $\mathrm{Al}$ and $\mathrm{Mg}$ sources $(1486.6 \mathrm{eV}, 12 \mathrm{kV}, 300 \mathrm{~W})$. The base pressure of the system was $5 \cdot 10^{-7} \mathrm{~Pa}$, and the measurements were conducted at $8 \cdot 10^{-7} \mathrm{~Pa}$ to $1 \cdot 10^{-6} \mathrm{~Pa}$. For each catalyst, a survey spectrum was collected before high-resolution spectra were recorded. Deconvolutions of XPS spectra were conducted using the software XPS Peak 4.1.

\subsection{Electrochemical measurements}

A model $760 B$ potentiostat/galvanostat ( $\mathrm{CH}$ Instruments, Inc., Austin, TX, USA) was used for electrochemical measurements in a standard three-compartment electrochemical cell. All electrochemistry experiments were conducted at room temperature. The working electrode was a glass $C$ disk with a diameter of $4 \mathrm{~mm}$ held in a Teflon cylinder. A Pt foil counter electrode and a saturated calomel reference electrode (SCE) (separated by an electrolyte salt bridge) were used. The working electrode was prepared as follows: Firstly, $5 \mathrm{mg}$ catalyst was mixed with $1 \mathrm{ml}$ ethanol and $5 \mu \mathrm{l} 5 \%$ Nafion solution. The mixture was ultrasonically suspended to obtain ink slurry. Then, $40 \mu$ l slurry was spread on the working electrode to form a thin layer. Linear sweep voltammetry (LSV) at a scan rate of $5 \mathrm{mV} \mathrm{s}^{-1}$ and chronoamperometry (CA) experiment at a scan rate of $50 \mathrm{mV} \mathrm{s}^{-1}$ were conducted in the electrolyte of $0.5 \mathrm{M}$ $\mathrm{H}_{2} \mathrm{SO}_{4}$, which contained $1 \mathrm{M}$ ethanol. Cyclic voltammetry $(\mathrm{CV})$ experiments were conducted in the electrolyte of $0.5 \mathrm{M} \mathrm{H}_{2} \mathrm{SO}_{4}$ at a scan rate of $50 \mathrm{mV} \mathrm{s}^{-1}$. Measurements were performed at room temperature, and the potentials reported in this paper were referenced to those of an SCE.

\section{Results and discussion}

The XRD patterns of the obtained $\mathrm{SnO}_{2}$ sample are shown in Fig. 1a. All peaks can be attributed to the diffraction of the tetragonal $\mathrm{SnO}_{2}$ (JCPDS Card No. 41-1445). The peaks located at approximately $27^{\circ}, 34^{\circ}, 52^{\circ}, 65^{\circ}$, and $72^{\circ}$ correspond to the (110), (101), (200), (211), (301), and (202) faces of the tetragonal $\mathrm{SnO}_{2}$, respectively. ${ }^{16}$ Fig. $1 \mathrm{~b}$ shows 

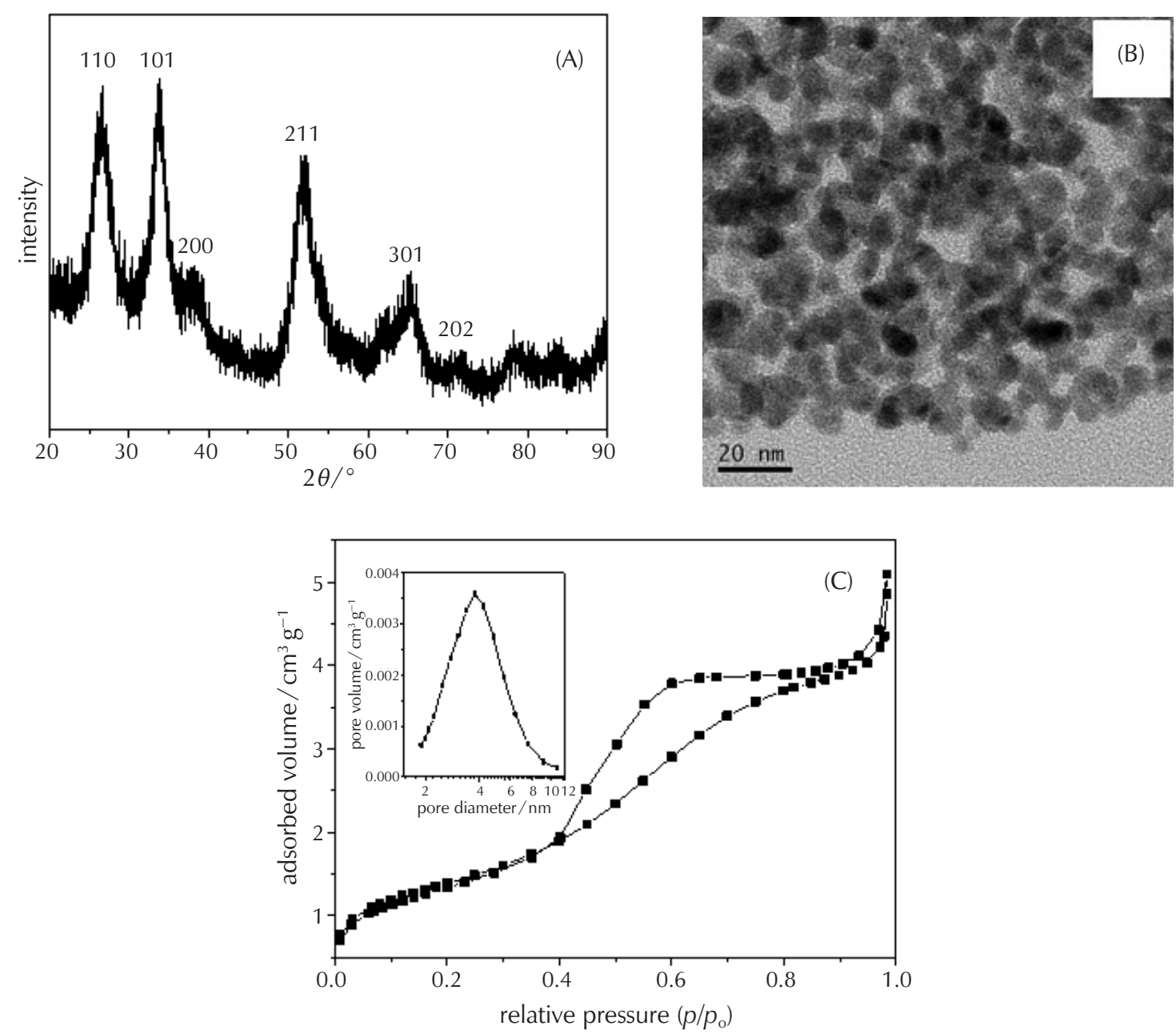

Fig. 1 - (A) XRD pattern, (B) TEM image, and (C) BET image of the as-synthesized mesoporous $\mathrm{SnO}_{2}$ nanomaterials

a typical TEM image of the $\mathrm{SnO}_{2}$ sample. Fig. 1c shows the nitrogen adsorption/desorption isotherm and the $\mathrm{BJH}$ pore size distribution plot of the as-synthesized mesoporous $\mathrm{SnO}_{2}$ nanomaterials. A classic type IV isotherm with a type $\mathrm{H} 3$ hysteresis loop resulted from the quadratic capillary condensation at an intermediate relative pressure $\left(p / p_{0}\right)$ of 0.4 to 0.9 , thus indicating the presence of a highly mesoporous structure. ${ }^{19}$ The surface area for $\mathrm{SnO}_{2}$ is $109 \mathrm{~m}^{2} \mathrm{~g}^{-1}$. Such structure produces a unimodal pore size distribution of $3.8 \mathrm{~nm}$, which was calculated from the desorption branch of the nitrogen adsorption isotherm.

Fig. 2 shows the TEM images of $\mathrm{Pt} / \mathrm{C}, \mathrm{PtSnO}{ }_{2}(\mathrm{~N}) / \mathrm{C}$, and $\mathrm{PtSnO}_{2}(\mathrm{M}) / \mathrm{C}$ catalysts. From Figs. 2a and 2c, it was observed that $\mathrm{Pt}$ and $\mathrm{PtSnO}_{2}(\mathrm{~N})$ nanoparticles are well dispersed on XC72R carbon black. The size of Pt nanoparticles (NPs) in $\mathrm{Pt} / \mathrm{C}$ ranges from 1.5 to $4.0 \mathrm{~nm}$, with an average value of $2.0 \mathrm{~nm}$ (Fig. 2b). The size of Pt NPs in $\mathrm{PtSnO}_{2}(\mathrm{~N}) / \mathrm{C}$ with diameters from 1.0 to $4.5 \mathrm{~nm}$, had an average value of $2.7 \mathrm{~nm}$ (Fig. 2d). For $\mathrm{PtSnO}_{2}(\mathrm{M}) / \mathrm{C}$ catalysts, size dispersion is difficult to determine because of their irregular shape. The selective deposition of Pt on mesoporous $\mathrm{SnO}_{2}$ results in poor dispersion (Fig. 2e). The high-resolution
(HR) TEM micrograph further shows that the size of Pt nanoparticles is estimated to be 1.5 to $7.5 \mathrm{~nm}$, with a mean value of $4.3 \mathrm{~nm}$ (Fig. 2f), which is larger than those of Pt/C and $\mathrm{PtSnO}_{2}(\mathrm{~N}) / \mathrm{C}$ catalysts (Fig. 3c). In addition, several researchers have reported that the ideal particle size for Pt and Pt-based electrocatalysts is within the range of 2.0 to $4.0 \mathrm{~nm} .{ }^{20}$ Therefore, the selected method can be suitable for preparing Pt-based catalysts.

Fig. 3 shows typical HRTEM images of $\mathrm{PtSnO}_{2}(\mathrm{~N}) / \mathrm{C}$ and $\mathrm{PtSnO}_{2}(\mathrm{M}) / \mathrm{C}$ catalysts. A $0.227 \mathrm{~nm}$ d-spacing was assigned to Pt (111), whereas a $0.335 \mathrm{~nm} d$-spacing was assigned to $\mathrm{SnO}_{2}$ (110). Compared with the lattice constant of pure Pt, the crystal lattice of $\mathrm{Pt}$ in the $\mathrm{PtSnO}_{2}(\mathrm{~N}) / \mathrm{C}$ and $\mathrm{PtSnO}_{2}(\mathrm{M}) / \mathrm{C}$ samples remains unchanged (Figs. $3 \mathrm{~b}$ and 3d). This phenomenon indicates that the $\mathrm{SnO}_{2}$ additive has no effect on the crystal lattice of Pt. In the HRTEM image of $\mathrm{PtSnO}_{2}(\mathrm{~N}) / \mathrm{C}, \mathrm{SnO}_{2}$ nanoparticles are observed in the vicinity of Pt particles (Fig. 3a). In the HRTEM image of $\mathrm{PtSnO}_{2}(\mathrm{M}) / \mathrm{C}$ (Figs. 3c and 3d), crystalline $\mathrm{SnO}_{2}$ nanoislands support and finely deposited Pt nanoislands are obviously presented. $\mathrm{Pt}$ and $\mathrm{SnO}_{2}$ nanoislands have more contact in $\mathrm{PtSnO}_{2}(\mathrm{M}) / \mathrm{C}$. 

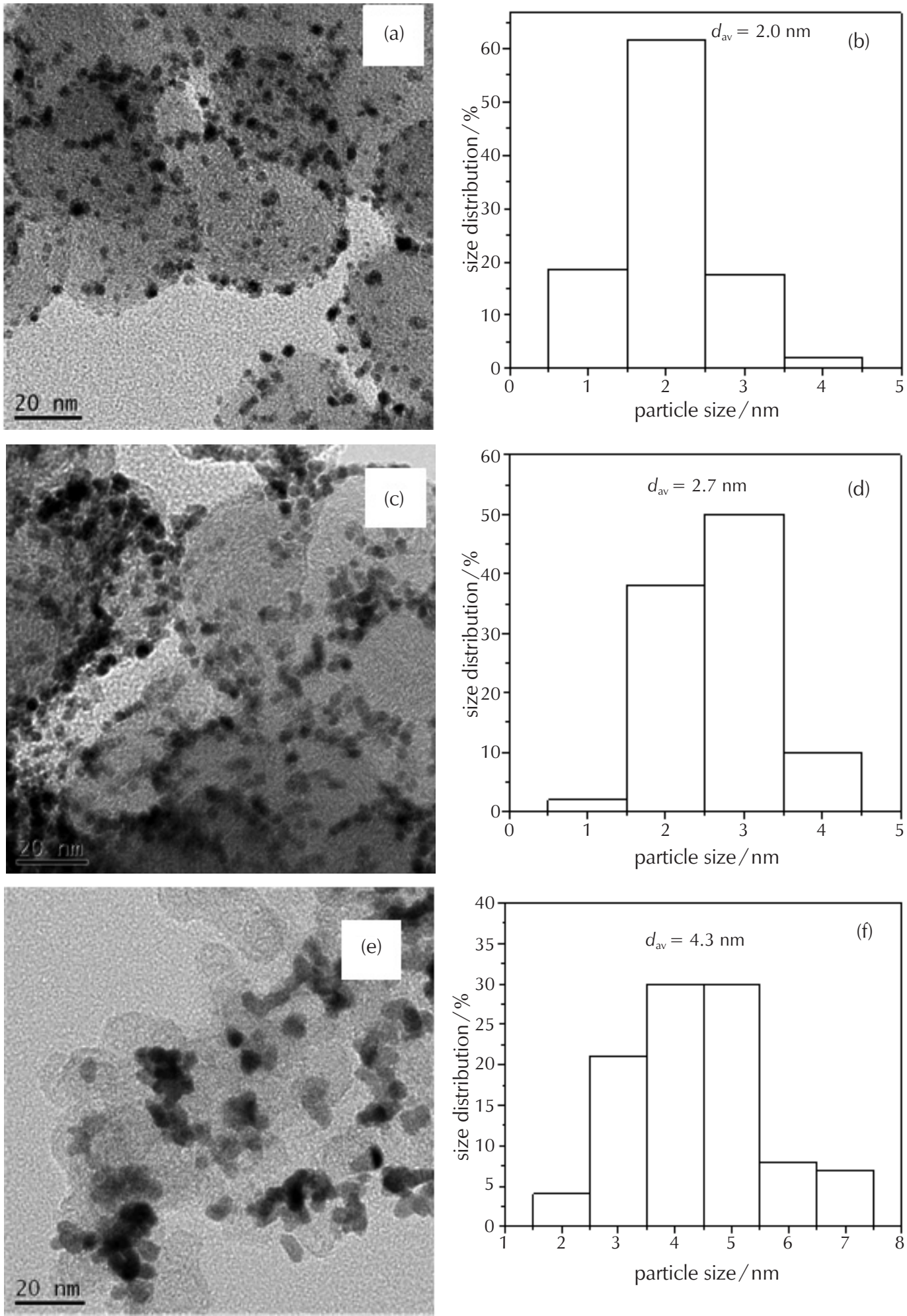

Fig. 2 - TEM images and size distribution of Pt nanoparticles in Pt/C (a,b), $\mathrm{PtSnO}_{2}(\mathrm{~N}) / \mathrm{C}(\mathrm{c}, \mathrm{d})$, and $\mathrm{PtSnO}_{2}(\mathrm{M}) / \mathrm{C}$ catalysts $(\mathrm{e}, \mathrm{f})$

The valences of $\mathrm{Pt}$ for $\mathrm{Pt} / \mathrm{C}, \mathrm{PtSnO}{ }_{2}(\mathrm{~N}) / \mathrm{C}$, and $\mathrm{PtSnO}{ }_{2}(\mathrm{M}) / \mathrm{C}$ catalysts were determined by XPS, as shown in Fig. 4a. Three different valences of Pt (0), Pt (II), and Pt (IV) are observed in the three samples, which are characterized by the doublet binding energy of $\mathrm{Pt} 4 \mathrm{f}_{7 / 2}$ and $\mathrm{Pt} 4 \mathrm{f}_{5 / 2} \cdot{ }^{21}$
Compared with the peaks of $\mathrm{Pt} 4 \mathrm{f}_{5 / 2}$ in $\mathrm{Pt} / \mathrm{C}$, the change in $\mathrm{PtSnO}_{2}(\mathrm{~N}) / \mathrm{C}$ value is negligible. However, the $\mathrm{Pt} 4 \mathrm{f}_{5 / 2}$ peaks of $\mathrm{PtSnO}_{2}(\mathrm{M}) / \mathrm{C}$ are approximately $0.4 \mathrm{eV}$ higher than those of $\mathrm{Pt} / \mathrm{C}$, which further demonstrates the interaction between $\mathrm{Pt}$ and mesoporous $\mathrm{SnO}_{2}$. This result was obtained 

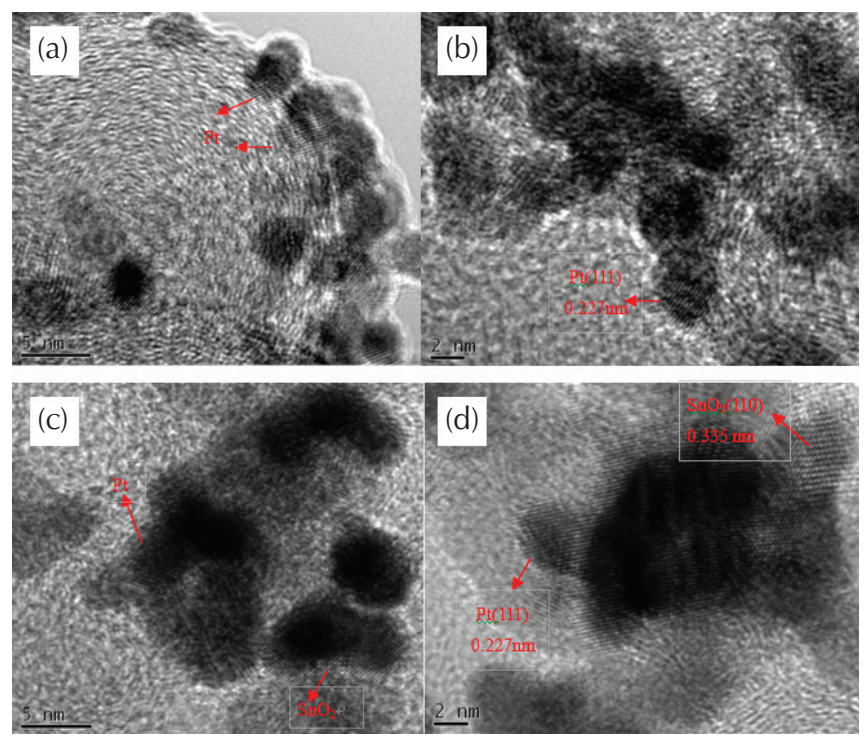

Fig. 3 - HRTEM images of (a and b) $\mathrm{PtSnO}_{2}(\mathrm{~N}) / \mathrm{C}$ and (c and d) $\mathrm{PtSnO}_{2}(\mathrm{M}) / \mathrm{C}$ catalysts

through HRTEM. In addition, the high-resolution XPS spectra of $\mathrm{Sn}_{3 d}$ in $\mathrm{PtSnO}_{2}(\mathrm{~N}) / \mathrm{C}$ and $\mathrm{PtSnO}_{2}(\mathrm{M}) / \mathrm{C}$ are shown in Fig. 4b. The XPS spectrum ranging from $482 \mathrm{eV}$ to $500 \mathrm{eV}$ that are assigned to two peaks, i.e., the $\mathrm{Sn} 3 \mathrm{~d}_{5 / 2}$ peak centred at $487.3 \mathrm{eV}$ and the $\mathrm{Sn} 3 \mathrm{~d}_{3 / 2}$ peak at $495.9 \mathrm{eV}$, agrees well with those reported in literature. ${ }^{22,23} \mathrm{All} \mathrm{Sn} 3 \mathrm{~d}_{5 / 2}$ signals are deconvoluted into two components that correspond to
$\mathrm{Sn}(\mathrm{II})(485.6 \mathrm{eV})$ and $\mathrm{Sn}(\mathrm{IV})(487.4 \mathrm{eV}) .^{24,25}$ The $\mathrm{Sn} 3 \mathrm{~d}_{5 / 2}$ peaks of $\mathrm{Sn}(\mathrm{II})(485.9 \mathrm{eV})$ and $\mathrm{Sn}(\mathrm{IV})(487.5 \mathrm{eV})$ are $0.2 \mathrm{eV}$ higher than those of $\mathrm{PtSnO}_{2}(\mathrm{~N}) / \mathrm{C}$ for Sn(II) $(485.6 \mathrm{eV})$ and $\mathrm{Sn}(\mathrm{IV})(487.3 \mathrm{eV})$. The change in $\mathrm{Sn}$ value in $\mathrm{PtSnO}_{2}(\mathrm{M}) / \mathrm{C}$ catalyst may be attributed to the change in its electronic structure.

ICP-AES was conducted to determine the actual content of the elements in the catalysts. As shown in Table 1, the mass fraction of $\mathrm{Pt}$ is $19.8 \%$ and $19.4 \%$, whereas that of $\mathrm{Sn}$ is $4.2 \%$ and $4.3 \%$ in $\mathrm{PtSnO}_{2}(\mathrm{~N}) / \mathrm{C}$ and $\mathrm{PtSnO}_{2}(\mathrm{M}) / \mathrm{C}$ catalysts, respectively. This result reveals that neither Pt nor $\mathrm{Sn}$ is dissolved during the preparation process. Fig. 5 shows the XRD patterns of $\mathrm{Pt} / \mathrm{C}, \mathrm{PtSnO}_{2}(\mathrm{~N}) / \mathrm{C}$, and $\mathrm{PtSnO}_{2}(\mathrm{M}) / \mathrm{C}$ catalysts. For the three samples, the peak at approximately $25^{\circ}$ is attributed to the diffraction at the (002) plane of the hexagonal structure of Vulcan XC72R carbon black. The other four diffraction peaks are characteristic of the face-centred cubic structure of $\mathrm{Pt}$, and correspond to the planes of Pt (111), Pt (200), Pt (220), and Pt (311) at approximately $40^{\circ}, 46^{\circ}, 67^{\circ}$, and $81^{\circ}$, respectively. These results were in good agreement with the Pt standard (JCPDS PDF\#04-0802) without any shift, which further indicated the absence of alloy formation between $\mathrm{Pt}$ and $\mathrm{Sn}$ and the presence of segregated $\mathrm{Pt}$ and $\mathrm{SnO}_{2}$ phases in $\mathrm{PtSnO}_{2}(\mathrm{M}) / \mathrm{C}$ and $\mathrm{PtSnO}_{2}(\mathrm{~N}) / \mathrm{C}$. In addition, the peaks in $\mathrm{Pt} / \mathrm{C}$ and $\mathrm{PtSnO}{ }_{2}(\mathrm{~N}) / \mathrm{C}$ catalysts are broader and weaker than those in $\mathrm{PtSnO}_{2}(\mathrm{M}) / \mathrm{C}$ catalyst, thus indicating the small size and low relative crystallinity of Pt nanoparticles in $\mathrm{Pt} / \mathrm{C}$ and $\mathrm{PtSnO}_{2}(\mathrm{~N}) / \mathrm{C}$ catalysts. ${ }^{23}$ This result matches well with the TEM analysis.
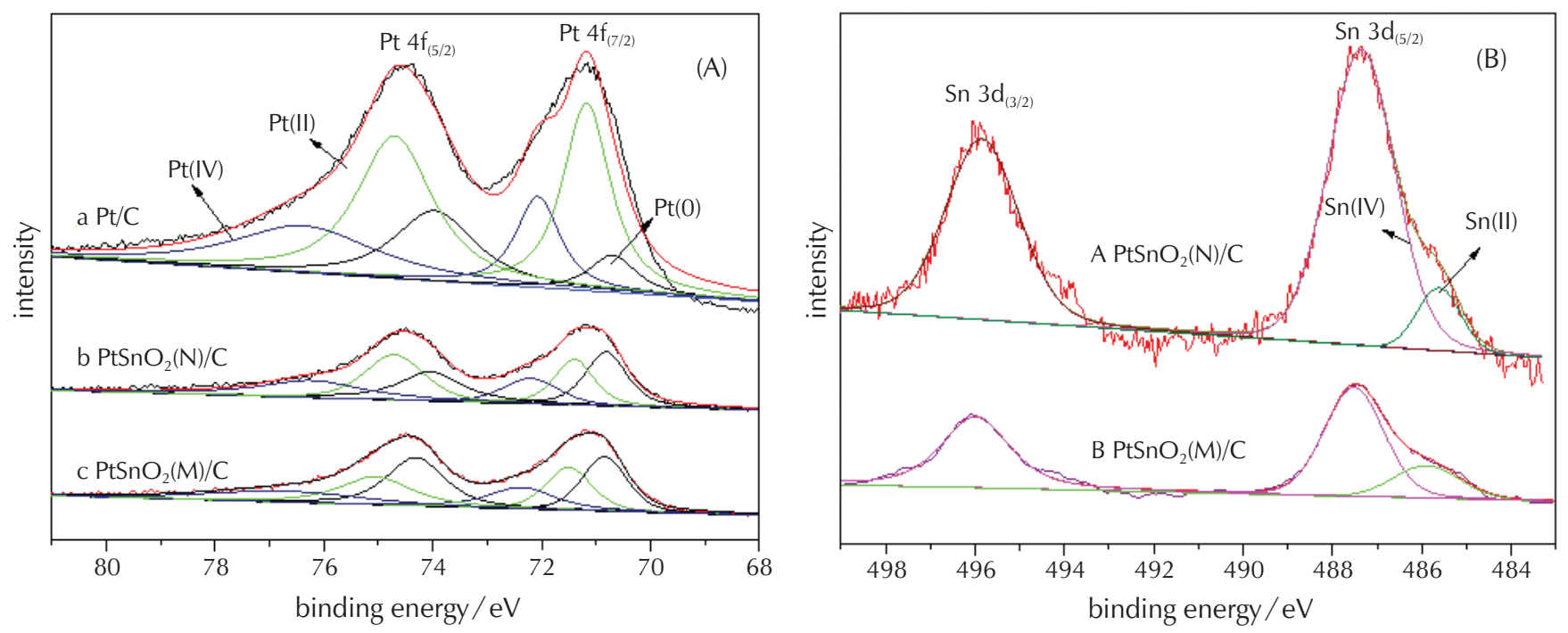

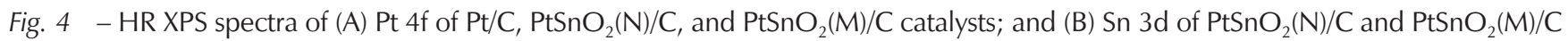
catalysts 


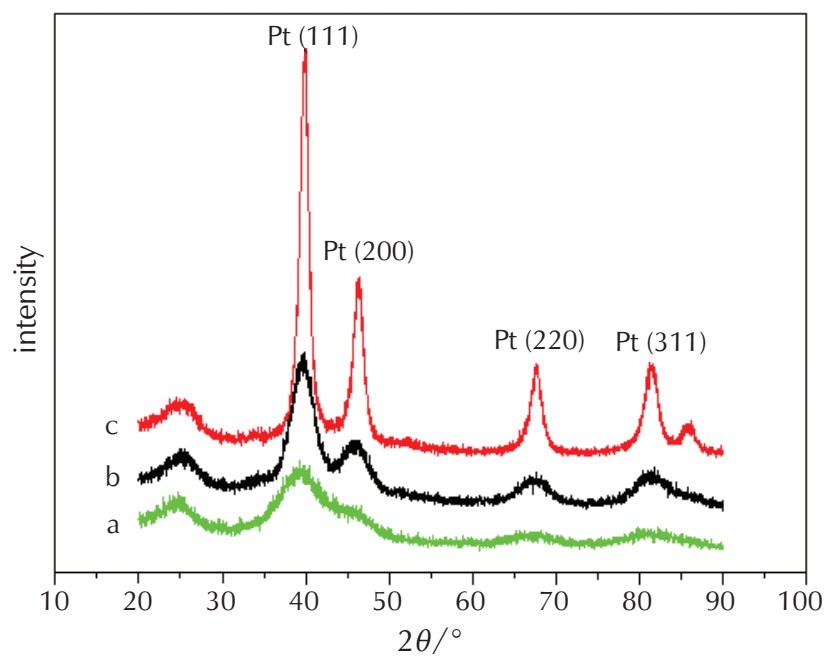

Fig. 5 - Wide-angle XRD patterns of (a) $\mathrm{Pt} / \mathrm{C}$, (b) $\mathrm{PtSnO}_{2}(\mathrm{~N}) / \mathrm{C}$, and (c) $\mathrm{PtSnO}_{2}(\mathrm{M}) / \mathrm{C}$ catalysts

Table 1 - Element components of $\mathrm{PtSnO}_{2}(\mathrm{~N}) / \mathrm{C}$ and $\mathrm{PtSnO}_{2}(\mathrm{M}) / \mathrm{C}$ catalysts

\begin{tabular}{|c|c|c|c|c|c|}
\hline \multirow{2}{*}{ Catalyst } & \multicolumn{2}{|c|}{ Nominal content } & \multicolumn{2}{|c|}{ Actual content } & \multirow{2}{*}{$(\mathrm{Sn} / \mathrm{Pt})_{\mathrm{actu}}$} \\
\hline & $w(\mathrm{Pt}) / \%$ & $w(\mathrm{Sn}) / \%$ & $w(\mathrm{Pt}) / \%$ & $w(\mathrm{Sn}) / \%$ & \\
\hline $\mathrm{PtSnO}_{2}(\mathrm{~N}) / \mathrm{C}$ & 19.96 & 4.15 & 19.8 & 42 & 0.343 \\
\hline $\mathrm{PtSnO}_{2}(\mathrm{M}) / \mathrm{C}$ & 19.96 & 4.15 & 19.4 & 4.3 & 0.349 \\
\hline
\end{tabular}

Fig. 6 shows the $\mathrm{CV}$ curves of $\mathrm{Pt} / \mathrm{C}, \mathrm{PtSnO}_{2}(\mathrm{~N}) / \mathrm{C}$, and $\mathrm{PtSnO}_{2}(\mathrm{M}) / \mathrm{C}$ electrodes in $0.5 \mathrm{M} \mathrm{H}_{2} \mathrm{SO}_{4}$ electrolyte at room temperature. Well-defined hydrogen adsorption-desorption peaks are observed in the potential region of -0.24 to $0.06 \mathrm{~V}$. The hydrogen adsorption/desorption and oxide reduction processes can be used to qualitatively evaluate electrode surface structures. ${ }^{26}$ We observed that the areas of hydrogen adsorption and desorption peaks in the order of $\mathrm{Pt} / \mathrm{C}>\mathrm{PtSnO}_{2}(\mathrm{~N}) / \mathrm{C}>\mathrm{PtSnO}_{2}(\mathrm{M}) / \mathrm{C}$ catalysts. However, in the double-layer capacitance region of $\mathrm{PtSnO}_{2}(\mathrm{M}) / \mathrm{C}$ catalyst, between 0.1 and $0.4 \mathrm{~V}$, a less capacitive current was observed than $\mathrm{PtSnO}_{2}(\mathrm{~N}) / \mathrm{C}$, indicating the conductivity of $\mathrm{PtSnO}_{2}(\mathrm{M}) / \mathrm{C}$ is better than $\mathrm{PtSnO}_{2}(\mathrm{~N}) / \mathrm{C}$. This effect could be due to the better conductivity of mesoporous $\mathrm{SnO}_{2}$ than $\mathrm{SnO}_{2}$ nanoparticles. The oxide reduction peak at over $0.5 \mathrm{~V}$ for $\mathrm{PtSnO}_{2}(\mathrm{M}) / \mathrm{C}$ catalyst is larger than $\mathrm{Pt} / \mathrm{C}$, indicating more Pt active sites in $\mathrm{PtSnO}_{2}(\mathrm{M}) / \mathrm{C}$ catalyst. The contradiction may be attributed to the fact that some of the Pt active sites for hydrogen and adsorption are blocked by $\mathrm{SnO}_{2} \cdot{ }^{21}$ The result suggests that the Pt nanoparticles may have been covered by mesoporous $\mathrm{SnO}_{2}$ successfully. The electrochemically active surface area (ECSA) is calculated by integrating the charge passing through the electrode during the hydrogen adsorption/desorption process after correcting the double layer formation. The charge required to oxidize a hydrogen monolayer is $0.21 \mathrm{mC} \mathrm{cm}^{-2}{ }^{27}$ The value of ECSA can be obtained through Eq. (1):

$$
\mathrm{ECSA} / \mathrm{m}^{2} \mathrm{~g}^{-1}=\frac{\mathrm{Q} / \mathrm{mC}}{0.21 \mathrm{mC} \mathrm{cm} \mathrm{cm}^{-2} \cdot \mathrm{m}(\mathrm{Pt}) / \mathrm{mg}} \times 10^{-1} .
$$

The specific ECSA of $\mathrm{PtSnO}_{2}(\mathrm{M}) / \mathrm{C}$ is $19.69 \mathrm{~m}^{2} \mathrm{~g}^{-1}$, which is $\sim 44 \%$ that of $\mathrm{Pt} / \mathrm{C}$ electrocatalyst $\left(44.98 \mathrm{~m}^{2} \mathrm{~g}^{-1}\right)$, and $\sim 67 \%$ that of $\mathrm{PtSnO}_{2}(\mathrm{~N}) / \mathrm{C}\left(29.73 \mathrm{~m}^{2} \mathrm{~g}^{-1}\right)$. The lower ECSA of $\mathrm{PtSnO}_{2}(\mathrm{M}) / \mathrm{C}$ catalyst can be attributed to its large nanoparticle size. Some Pt active sites for hydrogen adsorption are blocked by $\mathrm{SnO}_{2} \cdot{ }^{21,28}$

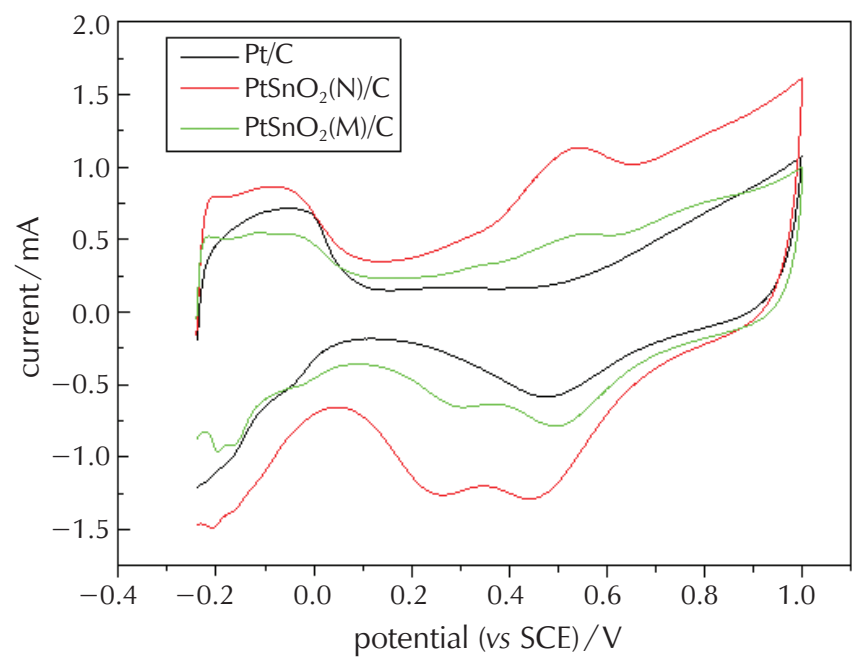

Fig. $6-\mathrm{CVs}$ of $\mathrm{Pt} / \mathrm{C}, \mathrm{PtSnO}_{2}(\mathrm{~N}) / \mathrm{C}$, and $\mathrm{PtSnO}_{2}(\mathrm{M}) / \mathrm{C}$ electrodes were measured in $0.5 \mathrm{M} \mathrm{H}_{2} \mathrm{SO}_{4}$ electrolyte at room temperature at a scan rate of $50 \mathrm{mV} \mathrm{s}^{-1}$

To evaluate the EOR catalysis of $\mathrm{PtSnO}_{2}(\mathrm{M}) / \mathrm{C}$ catalyst, LSV at a scan rate of $5 \mathrm{mV} \mathrm{s}^{-1}$ was conducted. As shown in Fig. $7 \mathrm{a}$, the onset potentials of $\mathrm{Pt} / \mathrm{C}, \mathrm{PtSnO}_{2}(\mathrm{~N}) / \mathrm{C}$, and $\mathrm{PtSnO}_{2}(\mathrm{M}) / \mathrm{C}$ are $0.203,-0.138$, and $-0.138 \mathrm{~V}$ (vs. SCE), respectively. The peak current densities in the three electrodes for ethanol are in the following order: $\mathrm{PtSnO}_{2}(\mathrm{M}) / \mathrm{C}>\mathrm{PtSnO}_{2}(\mathrm{~N}) / \mathrm{C}>\mathrm{Pt} / \mathrm{C}$, at less than $0.64 \mathrm{~V}$ (vs. SCE). $\mathrm{PtSnO}_{2}(\mathrm{M}) / \mathrm{C}$ electrode obviously exhibits an extremely high oxidation current density from the quasisteady-state polarization curves. Two oxidation peaks of ethanol oxidation can be observed on $\mathrm{PtSnO}_{2}(\mathrm{~N}) / \mathrm{C}$ and $\mathrm{PtSnO}_{2}(\mathrm{M}) / \mathrm{C}$ catalysts in the range of 0.2 and $0.8 \mathrm{~V}$, which is in accordance with literature results. ${ }^{8,23}$ According to the results reported in the literature, the second oxidation peak $(0.7 \mathrm{~V})$ corresponds mainly to the formation of $\mathrm{CH}_{3} \mathrm{COOH}$, whereas the first oxidation peak $(0.36 \mathrm{~V})$ corresponds mainly to the formation of $\mathrm{CH}_{3} \mathrm{CHO}$. It has been found that $\mathrm{CH}_{3} \mathrm{CHO}$ was formed on Pt surface at potentials lower than $0.6 \mathrm{~V}$ (vs. RHE). ${ }^{29}$ As soon as $\mathrm{CH}_{3} \mathrm{CHO}$ was formed, it adsorbed on Pt sites and formed $\mathrm{CH}_{3} \mathrm{CO}$ species, which blocked the subsequent oxidation of ethanol. ${ }^{30}$ $\mathrm{SnO}_{2}$ provides hydroxy radical species for the oxidation 

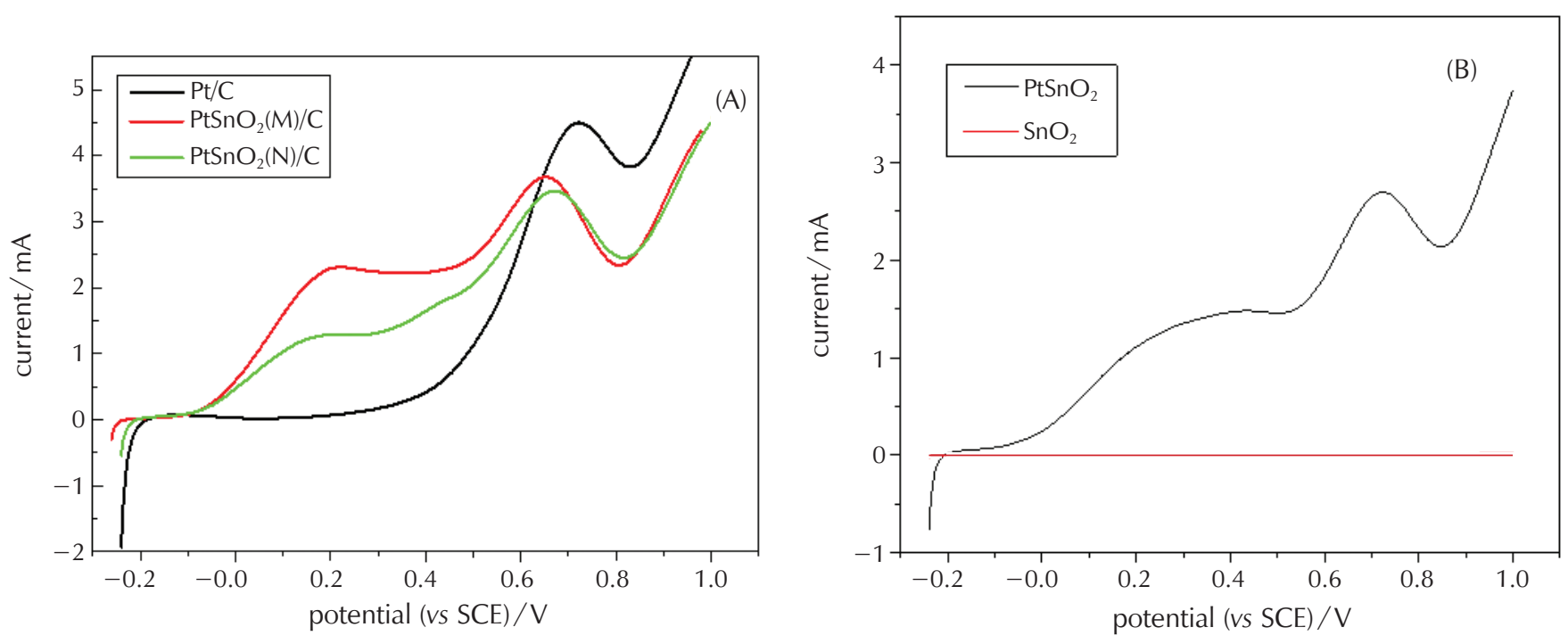

Fig. 7 - (A) LSV of Pt/C, $\mathrm{PtSnO}_{2}(\mathrm{~N}) / \mathrm{C}$, and $\mathrm{PtSnO}_{2}(\mathrm{M}) / \mathrm{C}$ in $0.5 \mathrm{M} \mathrm{H}_{2} \mathrm{SO}_{4}+1 \mathrm{M}$ EtOH electrolyte at room temperature at a scan rate of $5 \mathrm{mV} \mathrm{s}^{-1}$. (B) LSV of mesoporous $\mathrm{SnO}_{2}$ and $\mathrm{PtSnO}_{2}(\mathrm{M}) / \mathrm{C}$ in $0.5 \mathrm{M} \mathrm{H}_{2} \mathrm{SO}_{4}+1 \mathrm{M} \mathrm{EtOH}$ electrolyte at room temperature at a scan rate of $5 \mathrm{mV} \mathrm{s}^{-1}$.

of $\mathrm{CH}_{3} \mathrm{CHO}$ to $\mathrm{CH}_{3} \mathrm{COOH}$ at the potential values below $0.36 \mathrm{~V}$ (vs. SCE). Because the high activity of mesoporous $\mathrm{SnO}_{2}$ provides hydroxy radical species for the oxidation of $\mathrm{CH}_{3} \mathrm{CHO}$ to $\mathrm{CH}_{3} \mathrm{COOH}$, Pt sites are not blocked. The curve of $\mathrm{PtSnO}_{2}(\mathrm{M}) / \mathrm{C}$ catalyst is found quasi-steady-state polarization in the range of 0.2 and $0.5 \mathrm{~V}$ (vs. SCE). The LSV of EOR on the $\mathrm{SnO}_{2}$ and $\mathrm{PtSnO}_{2}(\mathrm{M})$ catalyst is also presented (Fig. 7b). Curve $\mathrm{SnO}_{2}$ shows that mesoporous $\mathrm{SnO}_{2}$ has no electrocatalytic activity for ethanol oxidation, which is in accordance with literature results. ${ }^{11}$ Two oxidation peaks of ethanol oxidation can be observed on $\mathrm{PtSnO}_{2}(\mathrm{M})$ catalysts, which is in accordance with $\mathrm{PtSnO}_{2}(\mathrm{M}) / \mathrm{C}$ results in Fig. $7 \mathrm{a}$. According to the results, $\mathrm{PtSnO}_{2}(\mathrm{M}) / \mathrm{C}$ catalysts have better performance due to higher activity of $\mathrm{PtSnO}_{2}(\mathrm{M})$. This result also indicated the interaction between $\mathrm{Pt}$ and $\mathrm{SnO}_{2}$.

The catalytic activities and stabilities of $\mathrm{Pt} / \mathrm{C}, \mathrm{PtSnO}_{2}(\mathrm{~N}) / \mathrm{C}$, and $\mathrm{PtSnO}_{2}(\mathrm{M}) / \mathrm{C}$ electrodes for EOR were investigated via $\mathrm{CA}$ measurements performed at $0.2 \mathrm{~V}$ for $2400 \mathrm{~s}$. The initial high current corresponds mainly to double-layer charging. A steady decrease in current is observed within the first few minutes for the three catalysts, followed by a fairly constant current for a longer period, which may be due to the poisoning effect of $\mathrm{CO}$-like species produced by the continuous oxidation of ethanol on the catalyst surface. In Fig. 8, the final current densities for $\mathrm{Pt} / \mathrm{C}, \mathrm{PtSnO}_{2}(\mathrm{~N}) / \mathrm{C}$, and $\mathrm{PtSnO}_{2}(\mathrm{M}) / \mathrm{C}$ after maintaining the cell potential are in the following order: $\mathrm{PtSnO}_{2}(\mathrm{M}) / \mathrm{C}>\mathrm{PtSnO}_{2}(\mathrm{~N}) / \mathrm{C}>\mathrm{Pt} / \mathrm{C}$. The $\mathrm{CA}$ curves indicate that the current density of $\mathrm{PtSnO}_{2}(\mathrm{M}) / \mathrm{C}$ is higher than those of $\mathrm{PtSnO}_{2}(\mathrm{~N}) / \mathrm{C}$ and $\mathrm{Pt} / \mathrm{C}$ during the entire time course, thus further verifying that $\mathrm{PtSnO}_{2}(\mathrm{M}) / \mathrm{C}$ exhibits better electrocatalytic performance in ethanol oxidation reaction. The improved anti-poisoning ability of the $\mathrm{PtSnO}_{2}(\mathrm{M}) / \mathrm{C}$ catalysts may be explained by the bifunction-

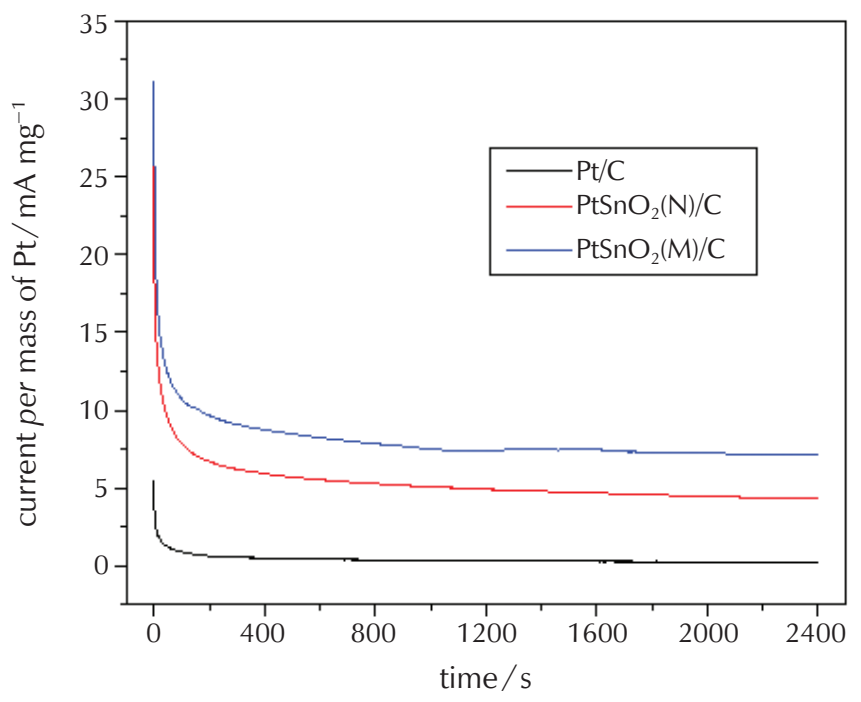

Fig. 8 -Current density - time dependence measured by the $\mathrm{CA}$ method in $0.5 \mathrm{M} \mathrm{H}_{2} \mathrm{SO}_{4}+1 \mathrm{M} \mathrm{EtOH}$ electrolyte on $\mathrm{Pt} / \mathrm{C}, \mathrm{PtSnO}_{2}(\mathrm{~N}) / \mathrm{C}$, and $\mathrm{PtSnO}_{2}(\mathrm{M}) / \mathrm{C}$ electrodes at $0.2 \mathrm{~V}$ (vs. SCE)

al mechanism and high activity of mesoporous $\mathrm{SnO}_{2}$ providing hydroxy radical species. The results are consistent with LSV measurements.

\section{Conclusion}

In summary, mesoporous $\mathrm{SnO}_{2}$ was prepared via a water-evaporating process. C-supported $\mathrm{PtSnO}_{2}(\mathrm{M})$ parti- 
cles with a nominal $\mathrm{Pt}: \mathrm{Sn}$ ratio of $3: 1$ were prepared via a modified polyol method. As-prepared $\mathrm{PtSnO}_{2}(\mathrm{M}) / \mathrm{C}$ exhibited enhanced electrocatalytic activity toward EOR compared with solid $\mathrm{PtSnO}_{2}(\mathrm{~N}) / \mathrm{C}$ and $\mathrm{Pt} / \mathrm{C}$ catalysts. The enhanced EOR activity could be attributed to the mesoporous structure of $\mathrm{SnO}_{2}$ and the strong chemical interaction between $\mathrm{Pt}$ and $\mathrm{SnO}_{2}$. This synthesis may lead to new development strategies to prepare EOR catalysts for DEFC.

\section{ACKNOWLEDGEMENTS}

This work was supported by the Foundation of Young Scientist of Shihezi University (2013ZRKXJQ03).

\section{List of abbreviations}

\begin{tabular}{|c|c|}
\hline EOR & - ethanol electro-oxidation reaction \\
\hline DEFC & - direct ethanol fuel cell \\
\hline EG & - ethylene glycol \\
\hline BET & - Brunauer-Emmett-Teller \\
\hline $\mathrm{BJH}$ & - Barrett-Joyner-Halenda \\
\hline XRD & - powder X-ray diffraction \\
\hline TEM & - transmission electron microscopy \\
\hline ICP-AES & $\begin{array}{l}\text { - inductively coupled plasma atomic emission } \\
\text { spectroscopy }\end{array}$ \\
\hline XPS & - x-ray photoelectron spectroscopy \\
\hline SCE & - saturated calomel reference electrode \\
\hline LSV & - linear sweep voltammetry \\
\hline CA & - chronoamperometry \\
\hline $\mathrm{CV}$ & - cyclic voltammetry \\
\hline ECSA & - electrochemical active surface area \\
\hline IRTEM & - high resolution transmission electron microsc \\
\hline
\end{tabular}

\section{References \\ Literatura}

1. Y. Lin, S. Zhang, S. Yan, G. Liu, The effect of Sn content in Pt-SnO ${ }_{2} / \mathrm{CNTs}$ for methanol electro-oxidation, Electrochim. Acta 66 (2012) 1-6, doi: https://doi.org/10.1016/j.electacta.2011.12.109.

2. W. J. Zhou, S. Q. Song, W. Z. Li, Z. H. Zhou, G. Q. Sun, Q. Xin, S. Douvartzides $P$. Tsiakaras, Direct ethanol fuel cells based on PtSn anodes: the effect of Sn content on the fuel cell performance, J. Power Sources 140 (2005) 50-58, doi: https:// doi.org/10.1016/j.jpowsour.2004.08.003.

3. J. C. M. Silva, R. F. B. De Souza, L. S. Parreira, E. T. Neto, M. L. Calegaro, M. C. Santos, Ethanol oxidation reactions using $\mathrm{SnO}_{2} @ \mathrm{Pt} / \mathrm{C}$ as an electrocatalyst, Appl. Catal. B-Environ. 99 (1-2) (2010) 265-271, doi: https://doi.org/10.1016/j.apcatb.2010.06.031.

4. M. Li, A. Kowal, K. Sasaki, N. Marinkovic, D. Su, E. Korach, P. Liu, R. R. Adzic, Ethanol oxidation on the ternary Pt-Rh-SnO $/ 2$ C electrocatalysts with varied Pt: Rh: Sn ratios, Electrochim. Acta 55 (2010) 4331-4338, doi: https://doi. org/10.1016/j.electacta.2009.12.071.

5. M. Li, D. A. Cullen, K. Sasaki, N. S. Marinkovic, K. More, R. R. Adzic, Ternary electrocatalysts for oxidizing ethanol to carbon dioxide: making Ir capable of splitting C-C bond, J. Am. Chem. Soc. 135 (2012) 132-141, doi: https://doi. org/10.1021/ja306384x.

6. L. Jiang, G. Sun, S. Sun, J. Liu, S. Tang, H. Li, B. Zhou, Q. Xin, Structure and chemical composition of supported Pt-Sn electrocatalysts for ethanol oxidation, Electrochim. Acta $\mathbf{5 0}$ (2005) 5384-5389, doi: https://doi.org/10.1016/j.electacta.2005.03.018.

7. H. L. Pang, J. P. Lu, J. H. Chen, C. T. Huang, B. Liu, X. H. Zhang, Preparation of $\mathrm{SnO}_{2}-\mathrm{CNTs}$ supported Pt catalysts and their electrocatalytic properties for ethanol oxidation, Electrochim. Acta 54 (2009) 2610-2615, doi: https://doi. org/10.1016/j.electacta.2008.10.058.

8. M. Zhu, G. Sun, Q. Xin, Effect of alloying degree in PtSn catalyst on the catalytic behavior for ethanol electro-oxidation, Electrochim. Acta 54 (2009) 1511-1518, doi: https://doi. org/10.1016/j.electacta.2008.09.035.

9. W.-P. Zhou, S. Axnanda, M. G. White, R. R. Adzic, J. Hrbek, Enhancement in ethanol electrooxidation by $\mathrm{SnO}_{x}$ nanoislands grown on Pt (111): effect of metal oxide-metal interface sites, J. Phys. Chem. C. 115 (2011) 16467-16473, doi: https://doi.org/10.1021/jp203770x.

10. W. Du, G. Yang, E. Wong, N. A. Deskins, A. I. Frenkel, D. Su, $X$. Teng, Platinum-Tin oxide core-shell catalysts for efficient electro-oxidation of ethanol, J. Am. Chem. Soc. 136 (2014) 10862-10865, doi: https://doi.org/10.1021/ja505456w.

11. X. Zhang, H. Zhu, Z. Guo, Y. Wei, F. Wang, Design and preparation of $\mathrm{CNT} @ \mathrm{SnO}_{2}$ core-shell composites with thin shell and its application for ethanol oxidation, Int. J. Hydrogen Energy 35 (2010) 8841-8847, doi: https://doi.org/10.1016/j. ijhydene.2010.05.127.

12. H. Zhang, C. Hu, X. He, L. Hong, G. Du, Y. Zhang, Pt support of multidimensional active sites and radial channels formed by $\mathrm{SnO}_{2}$ flower-like crystals for methanol and ethanol oxidation, J. Power Sources 196 (2011) 4499-4505, doi: https:// doi.org/10.1016/j.jpowsour.2011.01.030.

13. A. Kowal, M. Li, M. Shao, K. Sasaki, M. Vukmirovic, J. Zhang, N. Marinkovic, P. Liu, A. Frenkel, R. Adzic, Ternary Pt/Rh/ $\mathrm{SnO}_{2}$ electrocatalysts for oxidizing ethanol to $\mathrm{CO}_{2}$, Nat. Mater. 8 (2009) 325, doi: https://doi.org/10.1038/nmat2359.

14. Y. Bai, J. Wu, X. Qiu, J. Xi, J. Wang, J. Li, W. Zhu, L. Chen, Electrochemical characterization of $\mathrm{Pt}-\mathrm{CeO}_{2} / \mathrm{C}$ and $\mathrm{Pt}-\mathrm{Ce}_{\mathrm{x}}$ $\mathrm{Zr}_{1-x} \mathrm{O}_{2} / \mathrm{C}$ catalysts for ethanol electro-oxidation, Appl. Catal. B-Environ. 73 (2007) 144-149, doi: https://doi. org/10.1016/j.apcatb.2006.06.026.

15. D.-J. Guo, X.-P. Qiu, L.-Q. Chen, W.-T. Zhu, Multi-walled carbon nanotubes modified by sulfated $\mathrm{TiO}_{2}-\mathrm{A}$ promising support for Pt catalyst in a direct ethanol fuel cell, Carbon 47 (2009) 1680-1685, doi: https://doi.org/10.1016/j.carbon.2009.02.023.

16. G. Chen, Z. Wang, D. Xia, One-pot synthesis of carbon nanotube@ $\mathrm{SnO}_{2}$-Au coaxial nanocable for lithium-ion batteries with high rate capability, Chem. Mater. 20 (2008) 69516956, doi: https://doi.org/10.1021/cm801853c.

17. P. Manjula, R. Boppella, S. V. Manorama, A facile and green approach for the controlled synthesis of porous $\mathrm{SnO}_{2}$ nanospheres: application as an efficient photocatalyst and an excellent gas sensing material, ACS Appl. Mat. Interfaces 4 (2012) 6252-6260, doi: https://doi.org/10.1021/ am301840s.

18. Y. Chen, J. Ma, L. Yu, Q. Li, T. Wang, Mesoporous $\mathrm{SnO}_{2}$ nano- 
spheres formed via a water-evaporating process with superior electrochemical properties, Cryst. Eng. Comm, 14 (2012) 6170-6172, doi: https://doi.org/10.1039/c2ce25769f.

19. L. Wang, T. Fei, J. Deng, Z. Lou, R. Wang, T. Zhang, Synthesis of rattle-type $\mathrm{SnO}_{2}$ structures with porous shells, J. Mater. Chem. 22 (2012) 18111-18114, doi: https://doi. org/10.1039/c2jm32520a.

20. D. Zhao, B.-Q. Xu, Platinum covering of gold nanoparticles for utilization enhancement of Pt in electrocatalysts, Phys. Chem. Chem. Phys. 8 (2006) 5106-5114, doi: https://doi. org/10.1039/b610269g.

21. C. R Parkinson, M. Walker, C. F McConville, Reaction of atomic oxygen with a Pt (111) surface: chemical and structural determination using XPS, CAICISS and LEED, Surf. Sci. 545 (2003) 19-33, doi: https://doi.org/10.1016/j. susc.2003.08.029.

22. M. Batzill, U. Diebold, The surface and materials science of tin oxide, Surf. Sci. 79 (2005) 47-154, doi: https://doi. org/10.1016/j.progsurf.2005.09.002.

23. C. Hu, Y. Cao, L. Yang, Z. Bai, Y. Guo, K. Wang, P. Xu, J. Zhou, Preparation of highly dispersed $\mathrm{Pt}-\mathrm{SnO}_{x}$ nanoparticles supported on multi-walled carbon nanotubes for methanol oxidation, Appl. Surf. Sci. 257 (2011) 7968-7974, doi: https:// doi.org/10.1016/j.apsusc.2011.04.010.

24. K. Ke, K. Waki, Fabrication and Characterization of Multiwalled Carbon Nanotubes-Supported $\mathrm{Pt} / \mathrm{SnO}_{x}$ Nanocomposites as Catalysts for Electro-oxidation of Methanol, J. Electrochem. Soc. 154 (2007) A207-A212, doi: https://doi. org/10.1149/1.2426873.

25. R. Liu, S. Yang, F. Wang, X. Lu, Z. Yang, B. Ding, Sodium chloride template synthesis of cubic tin dioxide hollow particles for lithium ion battery applications, ACS Appl. Mat. Interfaces 4 (2012) 1537-1542, doi: https://doi.org/10.1021/ am201756m.

26. G. Neri, C. Milone, S. Galvagno, A. P. J. Pijpers, J. Schwank, Characterization of Pt-Sn/carbon hydrogenation catalysts, Appl. Catal. A 227 (2002) 105-115, doi: https://doi. org/10.1016/S0926-860X(01)00927-9.

27. E. P. Lee, Z. Peng, D. M. Cate, H. Yang, C. T. Campbell, Y. Xia, Growing Pt nanowires as a densely packed array on metal gauze, J. Am. Chem. Soc. 129 (2007) 10634-10635, doi: https://doi.org/10.1021/ja074312e.

28. Y. Du, B. Su, N. Zhang, C. Wang, A novel preparation method of Sn-modified Pt nanoparticles and application for methanol oxidation, Appl. Surf. Sci. 255 (2008) 2641-2645, doi: https://doi.org/10.1016/j.apsusc.2008.07.147.

29. H. Hitmi, E. M. Belgsir, J.-M. Léger, C. Lamy, R. O. Lezna, A kinetic analysis of the electro-oxidation of ethanol at a platinum electrode in acid medium, Electrochim. Acta. 39 (1994) 407-415, doi: https://doi.org/10.1016/00134686(94)80080-4.

30. F. Vigier, C. Coutanceau, F. Hahn, E. M. Belgsir, C. Lamy, On the mechanism of ethanol electro-oxidation on Pt and PtSn catalysts: electrochemical and in situ IR reflectance spectroscopy studies, J. Electroanal. Chem. 563 (2004) 81-89, doi: https://doi.org/10.1016/j.jelechem.2003.08.019.

\title{
SAŽETAK
}

\author{
Mezoporozni katalizator $\mathrm{PtSnO}_{2} / \mathrm{C}$ s povećanom katalitičkom aktivnošću \\ za elektrooksidaciju etanola \\ Siyu Chen, ${ }^{\mathrm{a}}$ Lei Shi ${ }^{\mathrm{a}, \mathrm{b}^{*}}$ i Liang Wang ${ }^{\mathrm{c}}$
}

U ovom radu prikazana je sinteza, karakterizacija i elektrokemijska ocjena mezoporoznog katalizatora $\mathrm{PtSnO}_{2} / \mathrm{C}\left(\mathrm{PtSnO}_{2}(\mathrm{M}) / \mathrm{C}\right)$, s nominalnim omjerom $\mathrm{Pt}: \mathrm{Sn}$ od $3: 1$. Karakterizacije Brunauer-Emmett-Tellerovom metodom i transmisijskom elektronskom mikroskopijom pokazale su očitu mezoporoznu strukturu $\mathrm{SnO}_{2}$ u katalizatoru $\mathrm{PtSnO}_{2}(\mathrm{M}) / \mathrm{C}$. Analiza rendgenskom fotoelektronskom spektroskopijom pokazala je interakciju između Pt i mezoporoznog $\mathrm{SnO}_{2}$. U usporedbi s $\mathrm{Pt} / \mathrm{C}$ i komercijalnim katalizatorima $\mathrm{PtSnO}_{2} / \mathrm{C}$, katalizator $\mathrm{PtSnO}_{2}(\mathrm{M}) / \mathrm{C}$ ima slabije aktivno mjesto, ali veću katalitičku aktivnost za reakciju elektrooksidacije etanola (EOR). Poboljšana aktivnost mogla bi se pripisati nanočesticama Pt pohranjenim na mezoporoznom $\mathrm{SnO}_{2}$, što bi moglo smanjiti količinu otrovnih međuprodukata proizvedenih tijekom elektrooksidacije etanola interakcijom između Pt i mezoporoznog $\mathrm{SnO}_{2}$.

\section{Ključne riječi}

Reakcija elektrooksidacije etanola, katalizator Pt-Sn, mezoporozni $\mathrm{SnO}_{2}$ pojačana katalitička aktivnost

\footnotetext{
a School of Chemistry and Chemical Engineering, Shihezi University, Shihezi, Xinjiang, 832 000, Kina

${ }^{\mathrm{b}}$ Key Laboratory for Green Processing of Chemical Engineering of Xinjiang Bingtuan, Shihezi, Xinjiang, 832 000, Kina ' Shandong University of Traditional Chinese Medicine, Shandong, 250 355, Kina
}

Izvorni znanstveni rad Prispjelo 3. srpnja 2017. Prihvaćeno 27. listopada 2017. 